\title{
I. PolíticAS E HISTORIAS
}

Matthew Bush, Un asunto familiar: entre afecto y violencia política en La hora azul de Alonso Cueto y Un lugar llamado Oreja de Perro de Iván Thays ........

Margarida Casacuberta, Don Julián y Son Excellence, de Jaume Sabartés: dos aportaciones a la novela del dictador por el secretario de Picasso ............... ARMANDo ChÁvez RiverA, Banquetes, hambrunas y libertad en la Cuba del siglo

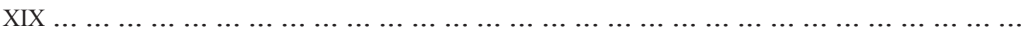

Claudia Darrigrandi, "Gente que uno ve pasar sin dejar huella": el roto en las portadas de la novela de Joaquín Edwards Bello ............................

Dafne Duchesne-Sotomayor, Del susurro al estruendo: la impolítica del amigo y el enemigo en El asalto de Reinaldo Arenas ......................

Ana SABAU, El espectro de Trotsky: política y escritura en Tres tristes tigres de Guillermo Cabrera Infante

Laura V. SÁndez, How to Do Things with activo desencanto: El discurso del desencanto en Los de abajo de Mariano Azuela

\section{AUTO-IMÁGENES Y CORPORALIDADES}

Claudia Cabello, La letra y el cuerpo: la imagen visual de Gabriela Mistral, $1905-1922$

LUIS H. CASTAÑEDA, Zonas de penumbra, fisuras profundas, oquedades abismales: autobiografía, ensayo y experiencia en El arte de la fuga de Sergio Pitol ..........

MaYa GonzÁlez Roux, Lecturas y autoconfiguración: Sylvia Molloy lectora de Victoria Ocampo 
Ivette GuZmán-Zavala, Colaboración y resistencia entre sangre y leche en Cuba y Puerto Rico: las nodrizas en Cecilia Valdés de Cirilo Villaverde y Vecindarios excéntricos de Rosario Ferré

\section{EstÉTICAS Y LENGUAJES}

Héctor JaImes, El espíritu vanguardista de Diego Rivera: Los murales de Chapingo .

Martha Elena Munguía Zatarain, Arte y teatralidad en Santa .

INGRID RoByn, Entre labios y ojos desligados. Vanguardia y artes visuales en Muerte de Narciso, de José Lezama Lima

Ofelia Ros, La infancia extrañando al dinero y al lenguaje en Potlatch, de Arturo Carrera

TomÁs VERA BARros, Estética y crítica de la literatura gauchesca (o la reescritura de una ficción cultural)

\section{RESEÑAS}

Kimberly A. Eherenman sobre Juan Rulfo, The Plain in Flames ... ... ... ... ..

MARK Frisch sobre Ramón Layera y Katie Gibson, You Have Nothing to Learn From Me: A Literary Relationship Between George Bernard Shay \& Rodolfo Usigli

Kayla Paulk sobre Nadia V. Celis y Juan Pablo Rivera, Lección errante: Mayra Santos Febres y el Caribe contemporáneo

YolANDA IzQUIERDO Collar sobre Anke Birkenmaier y Esther Whitfield, ed., Havana Beyond the Ruins: Cultural Mappings after 1989

Jesús Hidalgo sobre Darío Villanueva, Mario Vargas Llosa: La novela como literatura

Benigno Trigo sobre Mariselle Meléndez, Deviant and Useful Citizens: The Cultural Production of the Female Body in Eighteenth-Century Perú ...

Carlos Olivo Mendoza sobre Sergio Ugalde Quintana, La biblioteca en la isla. Una lectura de la Expresión americana, de José Lezama Lima ...

Hector E. Weir sobre Nancy Vogeley y Manuel Ramos Medina, coord., Historia de la literatura mexicana desde sus orígenes hasta nuestros días

IVONNE DEL VALLE sobre William Taylor, Marvels and Miracles in Late Colonial Mexico. Three Texts in Context.... 